\title{
PEMIKIRAN PEMBAHARUAN K.H. ABDUL WAHAB CHASBULLAH TERHADAP LAHIRNYA NAHDLATU ULAMA (NU)
}

\author{
Umi Masfiah \\ Balai Penelitian dan Pengembangan Agama Semarang \\ E-mail:masfiah_umi@yahoo.com
}

\begin{abstract}
This article is a study of renewal thinking of KH Abdul Wahab Chasbullah towards the birth of NU. It uses historical approach/method. The result of the discussion stated that K.H. Abdul Wahab Chasbullah is a qualified kiai. He had studied at Pesantren Tambakberas, Jombang, Langitan Tuban, Mojosari Nganjuk, Cepaka, Bangkalan, Tebu Ireng untul Mecca in the early 20th century. In the early 20th century, modernist ideas of reform were appearing in Mecca. These renewal ideas fostered the idea of renewal within Abdul Wahab. Upon his return from Makkah, he established the study institute Taswirul Afkar with K.H. Mas Mansur, educational institution Nahdhatul Wathan with K.H. Ahmad Dahlan, and Nahdlatut Tujjar in cooperation with K.H. Hasyim Ash'ari. The establishment of these three institutions has reflected the thinking of K.H. Abd Wahab Chasbullah towards the birth of Nahdlatul Ulama (NU).
\end{abstract}

Key Words: Abdul Wahab Chasbullah; Nahdlatul Ulama; Renewal Ideas

\begin{abstract}
ABSTRAK
Artikel ini merupakan study tentang pemikiran pembaharuan K.H. Abdul Wahab Chasbullah terhadap lahirnya NU, menggunakan metode pendekatan sejarah. Hasil pembahasan menyatakan bahwa K.H. Abdul Wahab Chasbullah seorang kiai yang mumpuni. Ia pernah menuntut ilmu di Pesantren Tambakberas, Jombang, Langitan Tuban, Mojosari Nganjuk, Cepaka, Bangkalan, Tebu Ireng hingga ke tanah suci Makkah awal abad ke-20. Awal abad ke-20, ide-ide pembaharuan kaum modernis sedang berlangsung di Makkah. Ide-ide pembaharuan ini menumbuhkan gagasan
\end{abstract}


pembaharuan dalam diri Abdul Wahab. Sepulangnya dari Makkah, ia mendirikan lembaga kajian Taswirul Afkar bersama K.H. Mas Mansur, lembaga pendidikan Nahdhatul Wathan bersama K.H. Ahmad Dahlan, dan koperasi Nahdlatut Tujjar bersama K.H. Hasyim Asy'ari. Berdirinya ketiga lembaga tersebut telah merefleksikan pemikiran pembaharuan K.H. Abd Wahab Chasbullah terhadap lahirnya Nahdlatul Ulama (NU).

Kata Kunci: Abdul Wahab Chasbullah; Nahdlatul Ulama; Pemikiran Pembaharuan

\section{A. Pendahuluan}

Nama K.H. Abdul Wahab Chasbullah (beserta tokoh NU lainya sejaman) merupakan tokoh-tokoh yang mempunyai nilai sejarah yang besar. Sejarah besar itu hingga kini masih melekat di hati masyarakat. Hal ini terbukti makam K.H. A. Wahab masih sangat ramai dikunjungi para peziarah dari berbagai daerah di Jawa. K.H. Abdul Wahab Chasbullah atau biasa disebut Mbah Wahab dalam pandangan kiai sepuh dari Lasem dikatakan sebagai seorang kiai yang mempunyai wawasan luas, berpandangan jauh, mempunyai cita-cita yang besar dan ada kemauan membawa umat Islam mencapai keselamatan dunia akhirat. (K.H.MZ, wawancara, Minggu: 26 Oktober 2013). Selain itu, Mbah Wahab menjadi salah satu kiai yang telah menorehkan sejarah besar tentang patriotisme ulama pesantren terhadap bangsa. Dauwes Dekker pernah mengatakan :

"jika tidak karena sikap kaum pesantren ini, maka gerakan patriotisme kita tidak sehebat seperti sekarang." (Saefudin Zuhri, 2012: 125)

Tahun 1916, K.H. Abd Wahab Chasbullah dan KH Ahmad Dahlan mendirikan Nahdhatul Wathan (NW) atau sekolah kebangsaan. Sekolah ini mengajarkan cinta tanah air, menggelorakan semangat kebangsaan para pemuda terhadap bangsanya. Sekolah ini mengajarkan kesadaran akan nasib bangsa yang sedang terjajah oleh kolonialisme Belanda, dan menanamkan sikap anti kolonialisme. (CA, wawancara, 08 Oktober 2013). Sebelum mendirikan Nahdhatul Wathan, K.H. A. Wahab Chasbullah telah mendirikan lembaga diskusi Taswirul Afkar bersama $\mathrm{KH}$ Mas Mansur, dan pada tahun 1918 mendirikan koperasi Nahdhatul Tujjar bersama $\mathrm{KH}$. Hasyim Asy'ari. Ketiga organisasi tersebut menjadi elemen penting pembentuk Nahdlatul Ulama (NU) tahun 1926. 
Setelah NU berdiri, KH Abd Wahab mengenalkan dan membangun NU ke daerah-daerah membuat organisasi para kiai ini menjadi besar. Sekiranya NU bagaikan seorang bayi maka KH Wahab adalah bidannya dan kiai Hasyim sebagai dokter. KH. Abd Wahab merupakan tokoh yang terlibat langsung dalam mempersiapkan kelahiran organisasi NU. Sedangkan Kiai Hasyim menjadi konsultan yang sangat bijak dalam pengambilan berbagai keputusan (Asry, 1993: 51). Bagi KH Abdul Wahab Chasbullah, NU menjadi salah satu karya monumental beliau. Mengenai hal ini Saefuddin Zuhri memberikan pernyataan sebagai berikut.

"Almarhum (KH. A. Wahab Chasbullah) telah menulis "Buku Besar" dengan "Huruf Besar" yang mudah dibaca oleh siapa pun. "Buku Besar" itu ialah sejarah perjuangannya, sepak terjangnya. "Buku Besar" itu ialah khidmahnya kepada Islam, kepada Indoesia dan bangsanya. Salah satu "huruf besar"nya yang mudah dibaca oleh semua orang adalah NU." (Saefudin Zuhri, 1999: 14)

Sosok kiai Wahab Chasbullah diakui sebagai ulama multi talenta. Sejak muda ia telah mendapat julukan contoh santri kelana paling bagus (Zamakhsyari Dhofier, 1982: 25). Sepulangnya dari tanah suci, A Wahab Chasbullah terlihat sebagai sosok yang memiliki kepekaan sosial tinggi, bersemangat, dan berkemauan keras serta memiliki minat membangun kerja sama dengan kaum muslimin (Haidar, 1994 : 44). Maka tidak mengherankan jika Wahab Chasbullah cukup dekat dengan tokoh-tokoh berpengaruh saat itu di Surabaya, seperti H.O.S. Cokroaminoto maupun Sutomo. Juga disebutkan kalau Abdul Wahab Chasbullah muda seringkali berkunjung kepada kiai A. Dahlan pimpinan Muhammadiyah di Yogyakarta untuk berdiskusi. Abdul Wahab memiliki semangat membangun jaringan pemikiran dan pergerakan dengan tokoh-tokoh lintas organisasi. Kaitannya dengan organisasi NU, Kiai A Wahab Chasbullah adalah ulama penggerak NU yang berada di belakang KH Hasyim Asy'ari (Martin van Bruinessen, 1999: 34). Saefuddin Zuhri menilai, kiai Wahab tidak saja menjadi motor penggerak NU tetapi sekaligus seorang ulama yang memberi konsep politik dengan bahasa ulama, menjadi tangan kanan dan juru bahasa $\mathrm{KH}$. Hasyim Asy'ari (Saefudin Zuhri, 1993: 38).

Berdasarkan pernyataan-pernyataan tersebut di atas dapat dimengerti jika peran K.H. Abd Wahab Chasbullah dan K.H. Hasyim Asy'ari sebagai perintis berdirinya NU tidak dapat dipisahkan. Tidak 
akan ada NU jika tidak ada K.H. Hasyim Asy'ari dan K.H. Abd Wahab Chasbullah bahkan tidak akan nada NU jika hanya ada salah satu saja, K.H. Hasyim Asy’ari atau K.H. Abd Wahab saja. Mengingat pentingnya peran kedua ulama tersebut, Greg Feally merekomendasikan perlu adanya kajian lebih jauh peran Hadratus Syaikh Hasyim Asy'ari dan K.H. Abd Wahab Chasbullah (Greg Feally, 1952-1967).

Kajian ini menitik beratkan pada pemikiran pembaharuan K.H. Abdul Wahab Chasbullah terhadap lahirnya organisasi Nahdlatul Ulama (NU). Pemikiran pembaharuan kiai Wahab penting dikaji mengingat ideide pembaharuan yang melandasi lahirnya organisasi NU menjadi pondasi penting berdiri tegaknya organisasi tersebut hingga sekarang.

Hierarki kiai di Jombang terletak pada pengakuan sosial, yakni kiai yang mengelola pesantren dianggap sebagai kiai yang memiliki derajat tinggi (Endang Turmudzi, 2004: 29). Secara lebih spesifik, Turmudzi mengkategorisasi kiai di Jombang ke dalam 4 jenis: kiai pesantren, kiai tarekat, kiai politik, dan kiai panggung. Kiai pesantren aktifitasnya mengajar di pesantren dengan pengikut para santri dari berbagai daerah, termasuk para orang tua santri. Kiai tarekat memusatkan kegiatannya dalam melayani batin (dunia hati) umat Islam. Anggota tarekat secara otomatis menjadi pengikut para kiai ini, dan pengikut kiai tarekat biasanya lebih banyak dari kiai pesantren karena memiliki cabang-cabang di berbagai daerah. Kiai panggung adalah para dai lokal yang menyebarkan Islam melalui kegiatan dakwah. Sedangkan kiai politik secara spesifik merujuk kepada para kiai yang mengembangkan NU secara politis, dimana sebagian besar kiai politik tidak memiliki pengikut (Ibid: 32-34).

Kategorisasi kiai yang dibuat oleh Turmudzi tidak berlaku untuk semua kiai, termasuk di antaranya Kiai Abd Wahab Chasbullah. Ia dapat masuk ke dalam kategori kiai pesantren sekaligus kiai politik. Sebagai kiai pesantren, Kiai Wahab Chasbullah merupakan cucu kiai Abdus Salam, pendiri pesantren Tambakberas, dan ia menjadi pengasuh Pesantren Tambakberas setelah ayahnya, Kiai Chasbullah wafat sampai tahun 1971. Ia juga mempelopori berdirinya lembaga pendidikan madrasah di pesantren Tambakberas, Jombang.

Sebagai kiai politik, kiai Wahab Chasbullah merupakan pendamping Kiai Hasyim Asy'ari saat membentuk, membesarkan, dan mengawal NU 
menjadi partai politik. Peran kiai Abd Wahab tersebut mengukuhkan peran seorang kiai dalam masyarakat. Horikoshi menyatakan bahwa peran kiai dalam masyarakat bukan hanya sebagai cultural broker (perantara budaya) sebagaimana disimpulkan oleh Geertz, tetapi bahwa kepemimpinan kiai telah tertanam kuat dalam struktur masyarakat karena kiai ikut terlibat langsung dalam proses perubahan sosial budaya itu sendiri (Hiroko Horikoshi, 1987: 241).

K.H. Abd. Wahab hidup pada awal abad ke- XX, masa berkembangnya ide-ide pembaharuan akibat pengaruh pemikiran Jamaluddin al-Afghani (1838 - 1897), Muhammad Abduh (1849 - 1905), dan Rasyid Rida (1865 - 1935). Inti dari ide pembaharuan ini bahwa kaum muslim sedang mengalami kemunduran akibat sikap taklid terhadap pemikiran abad pertengahan, dan akibat praktik-praktik amalan Islam yang tidak bersumber dari al-Qur'an dan hadis (Greg Feally: 26-27).

Reaksi ulama Indonesia terhadap isu modernisme beragam. Muhammadiyah (1912) melakukan pembaharuan dengan mendirikan sekolah-sekolah, rumah sakit, klinik, rumah yatim piatu dan menerapkan tekhnik manajemen modern. Diikuti oleh al-Irsyad (1914) dan Persis (1923) (Ibid: 29). Sedangkan kalangan ulama tradisonalis, dimotori oleh Abdul Wahab Chasbullah, juga telah mengadopsi ide-ide pembaharuan, seperti merintis berdirinya lembaga pendidikan madrasah, dan merintis organisasi NU.

\section{B. Pembahasan}

\section{Masa Muda Kiai Abd Wahab : Menjadi Santri Kelana}

KH. Abd Wahab Hasbullah lahir pada tahun 1888 M di Jombang. Hingga usia 13 tahun, Abd. Wahab dididik oleh ayahnya sendiri di pesantren Tambakberas. Sang ayah mengajarinya pelajaran dasar agama seperti membaca Qur'an, ilmu tauhid, fiqh, tasawuf, dan pelajaran bahasa Arab. Tamat dari pendidikan dasar di pesantren Tambakberas, Abd Wahab muda pergi berkelana mencari ilmu di beberapa pesantren di Jawa dan Madura.

Pesantren pertama yang dituju A. Wahab muda adalah Pesantren Pelangitan, Tuban lalu pergi ke Pesantren Mojosari di Nganjuk selama empat 
(4) tahun, berguru kepada kiai Saleh dan kyai Zaenuddin. Di pesantren ini beliau belajar tentang fikih Islam khususnya mengkaji kitab Fathul $M u^{\prime}$ in. Dari Pesantren Mojosari Abd Wahab pindah mondok ke pesantren Cepaka selama 6 bulan. Dari Pesantren Cepaka, Wahab Chasbullah belajar ke Pesantren Tawangsari dekat Surabaya. Ia memperdalam pengetahuan fikih khususnya kitab al-Iqna di bawah bimbingan kiai Ali. Lalu Abd Wahab muda pergi ke Pesantren Kademangan di Bangkalan, Madura belajar kepada Kiai Kholil selama 3 tahun. Di sini ia memperdalam pengetahuan dalam bidang tata bahasa Arab, linguistik, dan kesusteraan Arab. Usai tamat dari Pesantren Bangkalan, Wahab Chasbullah melanjutkan pelajarannya ke Pesantren Tebuireng Jombang di bawah asuhan Hadratus Syaikh Hasyim Asy'ari. Sebelum Wahab Chasbullah tinggal di pesantren Tebuireng, ia belajar tentang tafsir Qur'an, teologi Islam dan tasawwuf di pesantren Brangahan Kediri di bawah bimbingan Kyai Faqihuddin. Setelah dirasa cukup memiliki modal ilmu-ilmu agama, baru kemudian Abd Wahab Chasbullah nyantri di pesantren Tebuireng. (Dhofier, 1982 : 25 -26)

Begitu belajar di Pesantren Tebuireng, kiai Abdul Wahab langsung didapuk menjadi lurah pondok oleh kiai Hasyim Asy'ari dan menjadi anggota baru kelompok musyawarah. Kelompok musyawarah ini merupakan kelompok musyawarah para santri senior yang telah belajar di berbagai pesantren selama 10-20 tahun dan memiliki pengalaman mengajar. Para santri senior dididik dan dipersiapkan oleh Kiai Hasyim Asy'ari untuk menjadi kiai yang siap terjun di masyarakat. Kegiatan terpenting dari kelompok musyawarah ini adalah mengikuti seminarseminar yang membahas berbagai masalah atau soal-soal agama baik yang dipertanyakan oleh masyarakat maupun yang dilontarkan oleh kyai sebagai latihan memecahkan masalah (Zamakhsyari Dhofier: 26).

Kiai Wahab Chasbullah tinggal di Pesantren Tebuireng selama 4 tahun. Selesai mondok di Tebuireng, kiai Abd. Wahab disarankan oleh kiai Hasyim Asy'ari untuk pergi ke Makkah. Kondisi Makkah saat itu memainkan posisi penting jaringan para ulama Nusantara, khususnya melalui ajaran tarekat. Syaikh Ahmad Khatib Sambas, pencetus tarekat Qadiriyah wa an-Naqshabandiyah menjadi transmiter keilmuan para kiai Jawa. Salah satu karyanya adalah kitab Fath al-Arifin menjadi rujukan utama bagi para kiai. 
Selain Syaikh Ahmad Khatib Sambas, ia juga berguru kepada Syaikh Ahmad Khatib dari Minangkabau. Syaikh Ahmad Khatib ini menjadi guru dari Syaikh Hasyim Asy'ari, Kiai Abdul Wahab, kiai Bishri Syansuri, Achmad Dahlan dan lain-lain. (Dhofier, 1982 : 93). Syaikh Ahmad Khatib tidak menyetujui ide-ide Muhammad Abduh yang saat itu sedang giat-giatnya menganjurkan umat Islam melepaskan anutan-anutan terhadap madzhab yang empat. Tetapi Syaikh Ahmad Khatib sepakat dengan ide Muhammad Abduh tentang gerakan melawan segala bentuk praktek tarekat (Ibid: 94). Barangkali pemikiran Syaikh Ahmad Khatib yang seolah-olah anti tarekat cukup membekas dalam diri Abd Wahab Chasbullah sehingga sepanjang hidupnya tidak ditemukan pemikiran tentang tarekat pada diri Kiai A Wahab Chasbullah. Ia lebih tertarik pada ide-ide gerakan pembaharuan. Selain Syaikh Ahmad Khatib, ia juga berguru kepada Syaikh Mahfud alTarmisi (Ibid: 92). Kegigihan A. Wahab Chasbullah dalam berkelana mencari ilmu menjadikannya sebagai satu contoh santri kelana yang paling bagus dalam pandangan Zamakhsyari Dhofier.

\section{Kehidupan Rumah Tangga KH. Abd Wahab Chasbullah}

Setelah memperdalam ilmu agama di Makkah, ia menikah dengan Maimunah putri kiai Musa Kertopaten Surabaya. Dari perkawinan ini lahir seorang anak laki-laki bernama Wahib, yang dikenal pada masa selanjutnya dengan nama K. Kiai Wahab. Setelah istri pertamanya meninggal, kiai Wahab beberapa kali berumah tangga tetapi kurang berhasil.

Kemudian ia menikah dengan Aslihah, puteri H. Abdul Madjid dari Bangil. Dari perkawinan tersebut dikaruniai empat orang anak. Akan tetapi usia perkawinannya tidak berlangsung lama, karena Aslihah meninggal dunia. Setelah itu Kiai Abd. Wahab menikah dengan Sa’dijah, kakak kandung Aslihah. Kehidupan rumah tangga K. Wahab dengan Sa'diyah berlangsung hingga akhir hayat beliau dan memperoleh 5 orang anak yakni, Mahfuzah (10 tahun), Hasbijah (8 tahun), Mundjidah (6 tahun), Muhammad Hasib ( 5 tahun), dan Raqib (3 tahun).

\section{Profil KH. Abdul Wahab Chasbullah}

Menurut Kiai Nashir, salah seorang keponakan kiai Wahab, menganggap kiai Abdul Wahab merupakan tipe pemimpin yang tidak 
banyak dimiliki oleh para pemimpin lainnya. Di era 1940-an, ketika madrasah Mubdil Fann pesantren Tambakberas dipimpin oleh kiai Fatah, kiai A. Wahab sangat menghormati keputusan kiai Fatah meskipun pengasuhnya adalah Kiai Wahab Chasbullah. Berdasarkan kejadian ini Kiai Nashir menilai :

"Kepemimpinan kiai Wahab itu ngayomi. Ketika punya gagasan apapun nda pernah melangkahi kiai Fatah. Sebelum diterapno minta pendapat kiai Fatah dulu. Padahal kalau beliau langsung memutuskan tidak ada yang berani membantah." (kiai Nashir, wawancara, Sabtu 14 September 2013)

Kiai Wahab memiliki sikap rajin dan cekatan sebagaimana penuturan kiai Hasib. Meskipun baru datang malam hari dari perjalanan luar kota, tak segan kiai Wahab membetulkan apa saja yang perlu diperbaiki, seperti strongkin (lampu) bahkan juga mobil. (disarikan dari wawancara dengan kiai Hasib, Rabu, 11 September 2013). KH. Wahab Chasbullah seorang ulama yang tidak melupakan tanggungjawabnya sebagai kepala keluarga. Meskipun aktifitasnya padat, ia selalu menyempatkan diri berkumpul bersama keluarga sekitar 4-5 hari di Jombang. Untuk memenuhi kebutuhan keluarganya $\mathrm{KH}$. Abdul Wahab pernah menjadi seorang pedagang gula. Hasil perdagangan gula tersebut mampu menghidupi keluarganya, pesantren yang didirikan oleh ayahnya dan untuk membeli mobil "Opel Kapitan" tahun 1965 (Saefudin Zuhri: 113).

KH. A. Wahab Chasbullah dalam kesehariannya dekat dengan anak-anak dan keponakan-keponakan beliau. Beliau memiliki cara tersendiri yang membuat anak-anak merasa dekat dengannya. Kiai Nashir menceritakan kisah masa kecilnya hingga ia merasa memiliki hubungan yang erat dengan kiai Wahab meskipun ada perbedaan jenjang usia yang cukup jauh.

"Sering saya (Nashir), Mursi, Hasib itu main di depan rumahnya (kiai Wahab). Meneng-meneng mbah Wahab mencelat seko kamar.ciaaaat.. arek-arek do mlayu kabeh.terus mbah Wahab ngekek. Jadi saya merasa dekat ya karena itu candanya." (Kiai Nashir, wawancara, Sabtu 14 September 2013)

Sebagai seorang pengasuh pesantren, KH. A. Wahab Chasbullah tidak pernah melupakan kewajibannya mengajar ilmu agama kepada para santri. Saefuddin Zuhri ketika mendampingi perjalanan kiai Wahab dari Jakarta ke Jombang, pagi harinya setelah setengah jam istirahat sehabis 
solat Subuh, kiai Wahab langsung mengajar kitab kepada santri-santri Tambakberas. Keterangan Saefuddin Zuhri diperkuat oleh kesaksian kiai Nashir yang mengatakan :

"Kapan mulih langsung pengajian umum. Waktu itu yang diajari para santri senior ada juga yang kecil-kecil seperti saya ini masih teringat beberapa pengajian beliau. Waktu itu saya sering ikut mendengarkan pengajiannya." (Kiai Nashir, wawancara, Sabtu 14 September 2013)

Semangat mengajar kiai Wahab tidak pernah pupus meskipun mengalami sakit mata berkepanjangan hingga tidak dapat melihat. Dalam kondisi sakit mata dan tidak dapat melihat, beliau tetap mengajar kitab tafsir. Strategi yang dilakukan dalam kondisi demikian itu beliau menyuruh salah seorang santri senior membacakan kitab, lalu kiai Wahab mengartikan bacaan santrinya. Dari kegiatan pembacaan kitab ini dapat diketahui kalau KH. A. Wahab Chasbullah sangat menguasai materi kitab-kitab pesantren. Bagi Kiai Wahab Chasbullah, seorang ulama disebut sebagai ulama yang lengkap ketika ia mampu menguasai 3 (tiga) hal, yaitu : berilmu, kaya, dan sakti. Hal ini sebagaimana telah dinyatakan oleh Kiai Habib berikut ini.

"Kalau kamu ingin menjadi orang yang diperhitungkan orang ada tiga hal yang harus dikuasai, yaitu pertama memiliki ilmu atau mempunyai kualitas. Kedua harus kaya (sugih) dalam arti ekonomi cukup jangan sampai melarat. Ketiga sakti (jadug : Jawa) supaya disantet tidak mempan. (kiai Hasib, wawancara, Rabu, 11 September 2013)

Keahlian lain kiai Abd Wahab Chasbullah di mata para kiai NU adalah kemampuannya dalam berdebat. Chairul Anam, pengamat dan penulis buku Sejarah Nahdlatul Ulama memiliki pandangan yang sama dengan kiai sepuh dari Lasem mengenai keahlian berdebat kiai Abdul Wahab Chasbullah. Meskipun keduanya sepakat tentang keahlian berdebat kiai Abd Wahab tetapi kedua tokoh NU tersebut berbeda mengenai sumber kemampuan berdebat KH Abd Wahab. Khairul Anam menyatakan kalau keahlian debat kiai A. Wahab Chasbullah diperoleh ketika menuntut ilmu di Makkah terutama pengaruh kiai Hamid Surabaya (menetap di Makkah). (K. Anam, wawancara Selasa, 08 Oktober 2013). Sedangkan kiai MZ menganggap keahlian berdebat $\mathrm{KH} \mathrm{A}$. Wahab merupakan keahlian yang melekat pada dirinya karena telah di asah sejak lama melalui kegiatan Bahtsul Masail selama menjadi santri. (Kiai MZ., wawancara Minggu, 26 Oktober 2013). 
Selain dikenal sebagai ulama ahli debat, kiai Wahab dalam pandangan kiai Muchit Muzadi dianggap sebagai orang yang akalnya banyak. Salah satu contohnya yakni ketika masa penjajahan Jepang, muncul Lasykar Mujahidin dan Sabilillah. Kiai A. Wahablah yang mengkoordinir para kiai membentuk Barisan Kiai. Ia pergi ke daerah-daerah mengumpulkan dan melatih para kiai bersiap-siap melawan penjajah Jepang. (Kiai Muchit M., wawancara, Senin 21 Oktober 2013)

$\mathrm{KH}$ A Wahab Chasbullah telah diakui kapasitasnya sebagai seorang ulama yang memiliki keluasan ilmu dari gurunya sendiri $\mathrm{KH}$. Hasyim Asy’ari. Suatu saat kiai Masjkur dari Malang sowan ke kiai Hasyim menanyakan siapakah kiai Wahab Chasbullah yang hadir dalam mimpinya bersama kiai Hasyim. Hadratus syaikh KH. Hasyim mengatakan :

"sebaiknya ananda pergi kesana menemui ulama yang banyak ilmunya itu. Mungkin dengan berbincang-bincang dengan dia, ananda akan mendapat petunjuk serta bimbingan selanjutnya mengenai kesulitan yang ananda hadapi. "(Soebagijo, 1982: 18)

Saran KH Hasyim Asy'ari ternyata benar, setelah Masjkur pergi ke Surabaya menemui kiai Wahab Chasbullah, persoalan madrasahnya yang selama ini selalu mendapat kendala akhirnya dapat diselesaikan. Kiai Wahab memberi saran sederhana, mengganti nama madrasah yang semula Misbahul Wathan diubah menjadi Nahdhatul Wathan.

\section{Kiai Abdul Wahab Chasbullah: Perintis Berdirinya Nahdlatul Ulama (Tahun 1914 - 1926 )}

KH A. Wahab Chasbullah dikenal sebagai kiai pergerakan. Beliau aktif mendirikan organisasi-organisasi pergerakan. Dimulai ketika berada di Makkah, bersama Abbas dari Jember, Asnawi dari Kudus, dan Dahlan dari Kertosono mempelopori berdirinya Syarikat Islam (SI) cabang Mekkah (Aziz Masyhuri, 1999: 85). Pulang dari kota suci Makkah pada tahun 1914 kiai Abdul Wahab Chasbullah berciat-cita membangun lembaga pendidikan untuk menumbuhkan semangat nasioalisme pemuda terhadap tanah air. Pada saat yang sama pemuda Mas Mansur baru pulang dari Mesir. Keduanya bertemu, memiliki ide yang sama akhirnya sepakat mendirikan lembaga pendidikan. Ide ini mendapat sambutan dari para tokoh masyarakat seperti H.O.S Tjokroaminoto, Raden Pandji Soeroso, 
Soendjoto dan K.H. Abdul Kahar (Choirul Anam, 1985: 25).K.H. Abdul Kahar adalah seorang saudagar yang kaya raya, dan beliau pula yang menjadi donatur pembangunan gedung lembaga pendidikan tersebut.

Tahun 1916 akhirnya berdiri sebuah bangunan bertingkat yang cukup megah di Kampung Kawatan Surabaya, menjadi tempat berlangsungnya proses pendidikan dengan nama perguruan Nahdlatul Wathan (NW). Nahdlatul Wathan sendiri memiliki arti Pergerakan Tanah Air (Ibid: 26).Pada tahun 1916 ini pula, lembaga pendidikan ini mendapat Rechtspersoon (resmi berbadan hukum) dengan susunan pengurus $\mathrm{KH}$ Abdul Kahar sebagai Direktur, KH Abdul Wahab Chasbullah sebagai Pimpinan Dewan Guru (keulamaan) dan KH. Mas Mansur sebagai Kepala Sekolah dibantu KH. Ridwan Abdullah (Ibid: 25).

KH A Wahab Chasbullah menciptakan mars Nahdlatul Wathan yang syairnya berbahasa Arab untuk dinyanyikan pada setiap pembukaan pelajaran para murid. Mars Nahdlatul Wathan tersebut berisi syair semangat cinta tanah air dan menggemakan patriotisme kebangsaan di hati para pelajar. Sebelum berdiri NW, tahun 1914 sebenarnya Kiai Abdul Wahab bersama KH A. Dachlan, pengasuh Ponpes Kebondalem-Surabaya mendirikan lembaga diskusi "Taswirul Afkar”. Taswirul Afkar adalah semacam grup diskusi yang bertujuan menyalurkan aspirasi pemuda menghimpunnya dalam suatu ikatan dengan kegiatan membahas persoalan yang berkembang di masyarakat dari masalah keagamaan, perkembangan dunia internasional, hingga aspirasi akibat cengkeraman penjajah Belanda (Saefudin Zuhri: 29).Lembaga diskusi ini kemudian berkembang menjadi madrasah sekitar tahun 1919. Madrasah Taswirul Afkar berkembang pesat tanpa meniadakan kegiatan diskusi membahas masalah keagamaan dan sosial kemasyarakatan.

Surabaya saat itu menjadi pusat bagi pertumbuhan organisasi pergerakan dan menjadi kota tempat bertemunya para aktifis, dari kalangan tradisionalis dan modernis. Interaksi ini menyebabkan salah seorang pengurus NW yakni Mas Mansur meninggalkan NW dan koleganya pada tahun 1921. Kiai Mas Mansur hijrah ke Muhammadiyah, organisasi yang didirikan oleh KH Ahmad Dahlan di Yogyakarta. Sepeninggal Mas Mansur, kepala sekolah NW digantikan oleh KH. Mas Alwi. Di bawah kepemimpinan $\mathrm{KH}$ Mas Alwi, madrasah NW mulai dikembangkan ke 
berbagai daerah. Bersama dengan KH Mas Alwi, kiai Wahab membentuk cabang-cabang baru ; Akhul Wathan di Semarang, Far'ul Wathan di Gresik, Hidayatul Wathan di Jombang, Far'ul Wathan di Malang, Ahlul Wathan di Wonokromo, Khitabathul Wathan di Pancarkeling dan Hidayatul Wathan di Jagalan (Choirul Anam: 28).

Tahun 1922 ini pula diadakan Konggres Islam di Cirebon. Konggres ini diwarnai aksi debat hingga terdengar tuduhan "kafir" dan syirik dari kedua kubu yang berdebat. Saat itulah kiai Wahab meminta kiai Hasyim mendirikan perkumpulan. Kiai Hasyim belum dapat memutuskan usulan tersebut. Meski demikian, kiai Wahab tidak patah arang dan tidak mengendorkan semangat perjuangannya melalui wadah pergerakan. Maka ketika Dr Soetomo mendirikan organisasi "Indonesische Studieclub", kiai Wahab ikut bergabung di dalamnya (Ibid: 31). Keikut sertaan kiai Wahab dalam organisasi studiclub bentukan Dr Soetomo semakin menunjukkan kecenderungan kiai Wahab dalam dunia pergerakan. Pemikiran dan aktifitas beliau bersifat lintas komunitas, tidak terpaku pada satu komunitas tertentu. Ini yang menjadikan pergaulan kiai Wahab semakin luas dan membuat kiai Wahab mudah diterima oleh kelompok manapun. Pada sisi lain, gerakan kiai Wahab dengan organisasi SI (Syarikat Islam), pergaulannya dengan Mas Mansur dan Dr Soetomo dapat disebut sebagai upaya pembentukan jaringan kiai tradisional melalui lembaga organisasi. Jika selama ini jaringan kiai tradisional lebih banyak ditentukan karena ikatan perkawinan antar keluarga kiai dan jaringan karena hubungan antara murid dan guru, maka pada permulaan abad XX ini jaringan kiai mulai merambah karena hubungan organisasi. Fenomena ini harus diakui sebagai akibat pengaruh gerakan pembaharuan bagi kalangan kiai tradisional.

Kegiatan diskusi di studiclub bentukan Dr Soetomo tampaknya turut menginspirasi kiai Wahab untuk membentuk perkumpulan yang senada. Tahun 1924 kiai Wahab membuka kursus "masail diniyyah" (khusus masalah-masalah keagamaan). (Anam, 1985 : 29). Kursus ini dibentuk dalam rangka membekali para kiai muda mempertahankan diri dari serangan kaum anti madzhab. Kegiatan kursus dilakukan sebanyak tiga kali dalam satu minggu dan dilaksanakan di madrasah Nahdlatul Wathan. Kegiatan kursus "masail diniyyah" dibantu oleh beberapa kiai senior seperti KH. Bisyri Syansuri Jombang, KH Abdul Halim Leuwimunding Cirebon, 
KH Mas Alwi Abdul Azis dan KH Ridwan Abdullah dari Surabaya, KH Maksum dan KH Cholil dari Lasem, Rembang. Sedangkan dari kalangan tokoh muda ada Abdullah Ubaid, Kawatan - Surabaya, Thahir Bakri dan Abdul Hakim, Petukangan -Surabaya, serta Hasan dan Nawawi dari Surabaya (Choirul Anam: 29).

Keberadaan dan perkembangan madrasah Nahdlatul Wathan, madrasah Taswirul Afkar hingga perkumpulan "masail diniyyah" ini semakin mempererat hubungan di antara para kiai dan pada masa selanjutnya menjadi pondasi bagi gerakan yang lebih luas para tokoh pendukungnya, yakni pembentukan Komite Hijaz. Komite Hijaz lahir karena adanya berita yang datang dari negeri Mesir tentang adanya Konggres Khilafat untuk mempertahankan khalifah di Turki yang kalah dalam perang Dunia I (Saefudin Zuhri:31). Kabar adanya Konggres Khilafat menjadikan para ulama Nusantara bersiap-siap menghadiri kegiatan tersebut. Utusan yang dipilih untuk menghadiri Konggres Khilafat ternyata meniadakan wakil dari para ulama pesantren. Sehingga para ulama pesantren yang saat itu berada dalam organisasi Taswirul Afkar, Nahdhatul Wathan, dan Nahdlatut Tujjar membentuk sendiri organisasi perwakilan yang diberi nama Komite Hijaz.

Peran KH Abd Wahab dalam pembentukan Komite Hijaz adalah sebagai pemrakarsa terbentuknya Komite Hijaz, mulai dari menggagas pertemuan para kiai se Jawa Timur hingga mengawal komite ini melaksanakan dan menyelesaikan tugasnya (Martin van Bruinessen: 34). Setelah meminta restu kepada kiai Hasyim Asy'ari untuk mendirikan sebuah organisasi, kiai Wahab mengajak kiai Bisri berkeliling pulau Jawa, dari Banyuwangi di sebelah Timur, Menes di sebelah Barat hingga Madura, menemui para kiai untuk meminta dukungan (M. Solahudin, 2013: 71).

Berdasarkan pertemuan para kiai yang diselenggarakan di Surabaya pada tanggal 16 Rajab 1344 H - 31 Januari 1926, menghasilkan keputusan penting yaitu:

1. Mengirim delegasi ke Konggres Dunia Islam di Mekah untuk memperjuangkan kepada raja Ibnu Sa'ud agar hukumhukum menurut empat madzhab (Hanafi, Maliki, Syafi'i, dan Hambali) mendapat perlindungan dan kebebasan dalam wilayah kekuasaannya. 
2. Membentuk suatu Jam'iyyah bernama Nahdlatul Ulama (Kebangkitan Para Ulama) yang bertujuan menegakkan berlakunya syariat Islam yang berhaluan salah satu dari empat madzhab : Hanafi, Maliki, Syafi'i, dan Hambali. Jam'iyyah ini disusun dengan kepengurusan Syuriah dan Tanfidziyah (Saefudin Zuhri: 32-33).

Dua orang utusan yang dikirim ke Arab Saudi, KH. Abdul Wahab Chasbullah dan Syaikh Ghanaim pulang dengan membawa hasil yang memuaskan. Setelah itu Komite Hijaz bermetamorfosis menjadi organisai Nahdlatul Ulama dengan mengangkat KH. Hasyim Asy'ari sebagai Rois Akbar dan KH. Achmad Dahlan sebagai wakilnya. Presiden Tanfidziyah diserahkan kepada Haji Hasan Gipo dan KH Abdul Wahab Chasbullah menjabat sebagai Katib 'Am (penulis umum).

\section{Menjadi Pemrakarsa Komite Hijaz}

Alasan utama kelahiran Nahdlatul Ulama (NU) di masa- masa awal adalah karena adanya Komite Hijaz sebagaimana dikatakan Bruinessen ketika mengomentari peran kiai Wahab Chasbullah dalam merintis lahirnya NU. Bruinessen menyatakan :

Mendorong para kiyai terkemuka Jawa Timur agar mengirimkan utusan sendiri ke Makkah membicarakan masalah madzhab dengan Ibnu Saud. Mereka membentuk Komite Hijaz yang bertemu di rumahnya di Surabaya, 31 Januari 1926 untuk membicarakan siapa yanga akan diutus. Untuk lebih memperkuat kesan pihak luar, komite ini memutuskan mengubah diri menjadi sebuah organisasi menggunakan nama Nahdlatul 'Oelama. Pada masa beberapa tahun awal kehadirannya, pertimbangan mengenai status Hijaz nampaknya merupakan alasan tunggal kehadirannya. (Martin van Bruinessen: 34)

Pernyataan Bruinessen menegaskan kalau pertemuan pembentukan Komite Hijaz sebenarnya juga perkumpulan para kiai membentuk Nahdlatul Ulama. Tetapi perlu diketahui bahwa proses lahirnya NU melalui persiapan panjang karena sebenarnya kiai Wahab telah mempersiapkannya bertahun-tahun, sambil menunggu kesiapan KH Hasyim Asy'ari berkenan menjadi Rois Akbar. Kiai Abdul Wahab sebelum lahirnya NU pernah mengatakan :

"Saya sudah sepuluh tahun lamanya memikirkan membela para ulama (madzhab) yang diejek sana sini dan amaliyahnya diserang sana sini. Kalau satu kali ini ternyata luput, saya akan memilih di antara dua : masuk 
organisasi bentrokan terus, atau pulang kampung memelihara pondok secara khusus. "(Anam: 55)

Kiai Wahab telah memikirkan dan merintis organisasi NU sejak sepuluh tahun sebelum NU secara resmi berdiri. Itu berarti sejak tahun 1916, kiai Wahab telah mempersiapkan langkah-langkah mendirikan NU. Dengan demikian, pendirian Nahdlatul Wathan tahun 1916 merupakan upaya nyata kiai Wahab mewujudkan cita-citanya. Jika bicara NU maka tidak dapat dilepaskan dari sosok kiai Wahab dan sosok $\mathrm{KH}$ Hasyim Asy'ari.

Proses kelahiran NU, pada masa-masa awal berjalan cukup alot, karena kiai Hasyim Asy'ari sebagai sesepuh para kiai di Jawa dan telah disiapkan untuk menjadi pimpinan utama teryata tidak langsung menerima tawaran tersebut. Baru setelah kiai Kholil, sang guru kiai Hasyim Asy'ari ikut andil meyakinkan Hadratus Syaikh Hasyim Asy'ari, maka beliau berkenan menerima kepemimpinan di NU.

Mengenai peran kiai Kholil dalam meyakinkan kiai Hasyim agar mau menerima tongkat kepemimpinan Nahdlatul Ulama sebenarnya telah dilakukan sejak tahun 1925. Diceritakan kalau Kiai Kholil mengutus As'ad Syamsul Arifin muda, yang sedang nyantri di pondok Demangan Bangkalan mengantarkan tasbih kepada kiai Hasyim di Tebu Ireng. Kiai Cholil mengalungkan tasbih ke leher kiai As'ad sambil membaca lafad Yaa Qahhar..Yaa Jabbar 3 kali. Kyai As'ad terus berangkat ke Jombang jalan kaki. Tidak lama berselang, masih dalam tahun 1925, kyai As'ad disuruh mengantarkan tongkat kepada kyai Hasyim lagi. Setelah tongkat diterima, kiai As'ad disuruh membaca al-Qur'an, surat Thaaha ayat $17-25$ " (Mu'tamar NU, 1984). Berdasarkan pesan kiai Kholil melalui kiai As'ad itulah akhirnya kiai Hasyim Asy’ari mengerti kalau gurunya, kiai Kholil Bangkalan telah memberikan restu kepadanya untuk menerima usulan kiai-kiai lainnya mendirikan organisasi Nahdlatul Ulama dan menerima jabatan sebagai Rois Akbar.

Kisah lain tentang kelahiran NU menurut pendapat Choirul Anam (1985 : 32) bahwa keterlibatan kiai Abdul Wahab Chasbullah dalam organisasi Syarikat Islam, Indisische Studieclub, Nahdlatul Wathan, Taswirul Afkar, hingga masail diniyyah adalah untuk membangkitkan semangat 
nasionalisme bangsa yang sedang terjajah. Kiai Abdul Halim pernah mengajukan pertanyaan kepada kiai Wahab mengenai pembentukan perkumpulan ulama pada tanggal 31 Januari 2013 apakah mengandung tujuan menuntut kemerdekaan? Dijawab oleh kiai Wahab demikian :

"Tentu, itu syarat nomor satu. Umat Islam menuju ke jalan itu. Umat Islam tidak leluasa sebelum negara kita merdeka." Karena belum puas kiai Halim bertanya lagi : "apakah usaha semacam begini bisa menuntut kemerdekaan ? Kiai Wahab kemudian mengambil satu batang korek dan menyulutkannya, sambil berkata : ini bisa menghancurkan bangunan perang. Kita jangan putus asa. Kita harus yakin tercapai negeri merdeka." (Anam: 32 -33)

Berdasarkan dialog tersebut menunjukkan bahwa semangat nasionalisme kiai Wahab telah terbentuk sejak awal mula merintis lembaga pendidikan dan organisasi keagamaan.

\section{KH Abdul Wahab Chasbullah Wafat}

Kiai Wahab wafat 4 hari sesudah acara muktamar selesai. Saat muktamar NU yang ke-25 berlangsung, kiai Wahab tidak lagi bisa melaksanakan pidato. Pembacaan pidato rois am dibacakan oleh kiai Bisri Syansuri selaku wakil kiai Abd Wahab di dewan Syuriah. Setelah pidato pertanggungjawaban selesai dan hadirin menyatakan menerima, mendadak mbah Wahab itu minta pulang : " mulih saiki aku wis lego (pulang sekarang aku sudah lega)”. (wawancara, kiai Hasib, Rabu, 11 September 2013). Akhirnya saat itu pula mencari sopir lalu mengantar mbah Wahab pulang. Dan memang terbukti setelah muktamar hanya berjarak 4 hari, kiai Wahab wafat. KH. A. Wahab Chasbullah wafat pada hari Rabu 29 Desember 1971 pukul 10.00 WIB dan dimakamkan pada hari itu juga pada jam 17.00 WIB.

\section{Simpulan}

KH. Abdul Wahab Chasbullah adalah seorang kiai pesantren yang hidup di awal abad XX dimana ide-ide pembaharuan Islam sedang tumbuh. Meskipun tidak secara total mengadopsi ide pembaharuan Islam tetapi secara substansi, kiai Wahab sesungguhnya telah mengaplikasikan pemikiran pembaharuan sekaligus menanamkan nasionalisme kebangsaan melalui lembaga pendidikan Nahdlatul Wathan, Taswirul Afkar, dan menjadi perintis, dan pengawal berdirinya NU. 


\section{BIBLIOGRAFI}

Anam, Choirul, 1985. Pertumbuhan dan Perkembangan Nahdlatul Ulama, Sala : Jatayu

Asry, Zul LA. , 1993. Nahdlatul Ulama, Studi tentang Faham Keagamaan dan Pelestariannya Melalui Lembaga Pendidikan Pesantren, Pekan Baru : CV. Fajar Harapan

Bruinessen, Martin van, 1999. Tradisionalist Muslims in A Modernizing World: The Nahdlatul Ulama and Indonesia's New Order Politics, Factional Conflict and The Search for A New Discourse (Manuskrip) (terj. NU Tradisi Relasi-Relasi Kuasa Pencarian Wacana Baru) cet. Ketiga, Yogyakarta : LKiS

Dhofier, Zamakhsyari, 1982 Tradisi Pesantren Studi Tentang Pandangan Hidup Kyai

Fealy, Greg, 2009, Ulama and Politics in Indonesia a History of Nahdlatul Ulama (terj. Ijtihad Politik Ulama Sejarah NU 1952 - 1967), (terj. Farid Wajidi, Mulni Adelina Bachtar), Yogyakarta : LKiS

Horikoshi, Hiroko, 1987. Kyai dan Perubahan Sosial, Jakarta : Perhimpunan Pengembangan Pesantren dan Masyarakat (P3M)

I.N., Soebagijo, 1982. K.H. Masjkur Sebuah Biografi, Cet. 1, Jakarta: Gunung Agung

Kuntowijoyo, 2003. Metodologi Sejarah, Edisi Kedua, Yogyakarta: Tiara Wacana

Masyhuri, 2010. 99 Kiai Kharismatik Indonesia, Biografi, Perjuangan, Ajaran, dan Doa-Doa Utama yang Diajarkan, jilid kedua, Jombang: Pustaka Anda

Panitia Daerah Mu'tamar, t.th. NU ke-27, Bunga Rampai Mu'tamar NU ke27 dan Konggres Mu'tamar NU ke-11, Fatayat NU ke-9, Mu'tamar NU ke-27 di Situbondo 8 s/d Desember 1984, Situbondo : Panitia Daerah Mu'tamar 
Solahudin, M. 2013. Napak Tilas Masyayikh, Biografi 25 Pendiri Pesantren Tua di Jawa - Madura, (Kediri: Nous Pustaka Utama

Turmudzi, Endang. 2004. Perselingkuhan Kiai dan Kekuasaan, Yogyakarta : LkiS

Zuhri, Saefudin, Kaleidoskop Politik di Indonesia, Jakarta: Gunung Agung , 1999. Almaghfurlah KH. A. Wahab Chasbullah Bapak dan Pendiri Nahdlatul Ulama, Semarang: PT Karya Toha Putra , 2012. Guruku orang-Orang dari Pesantren, Cet. III, Yogyakarta : LKiS. 